\title{
Stunting Risk Factors Based on Priority Region in Indonesia: 2018 National Basic Health Survey
}

\author{
Mahalul Azam ${ }^{1}$, Muhamad Zakki Saefurrohim², Syed Mohamed Aljunid ${ }^{3}$ \\ \{mahalul.azam@mail.unnes.ac.id ${ }^{1}$, saefurrohim@students.unnes.ac.id ${ }^{2}$, \\ saljunid@gmail.com ${ }^{3}$ \} \\ Universitas Negeri Semarang, Semarang, Indonesia ${ }^{12}$ \\ Kuwait University, Kuwait City, Kuwait ${ }^{3}$
}

\begin{abstract}
Current study aimed to explore the risk factors of stunting based on priority-region status in Indonesia. We extracted national basic health survey in 2018. We defined stunting based on height for age, which Z-score<-2.0, was categorized as stunting. Priority-region categorized by the National Team for Acceleration of Poverty Reduction, Republic of Indonesia, i.e., 100 priorityregions determined. We also observed children's characteristics, i.e., age, sex, birth weight and height, gestational age, weaning age, diarrhea, immunization, breastfeeding, and supplementary feeding. Parent's and household's characteristics were observed as well. Binary regression logistic was performed to conclude risk factors of stunting. We concluded that male children, lower mother's and father's height were the consistent risk factors for priority-, non-priority, and total-regions. Without consider priority-region, we concluded that family members, sex, access to health services, antenatal-care, mother's- and father' sheight, parent's education level, and ferrous-sulfate supplementation altogether were the risk factors for stunting in Indonesia.
\end{abstract}

Keywords: stunting, risk factors, priority region, Indonesia

\section{Introduction}

Stunting is a health problem in children that the most burdened in developing countries[1]. Decreasing stunting is one priority of the six goals of the Global Nutrition Targets in 2025.[2] Children are determined as stunted if their height for age Zscore were $\leq 2$ from the standard deviations [SD][3]. Stunting causes $14.5 \%$ of deaths each year. Studies also concluded that there is a link between stunting and cognitive impairment[4][5][6]. Prolonged impairment of cognitive function in children with stunting will affect productivity and economic status[7][8][9]. Other studies have shown that school dropout rates for children with stunting are higher than for normal children[8].

The prevalence of stunting in Indonesia is 30.5\%[10], placed comparable to other countries with high stunting burdens[11]. Indeed, the prevalence decreased compared to the previous Indonesia national basic health survey (riset kesehatan dasar: 
RISKESDAS) 2013, i.e., 37.2\%[12] but must still be concerned. In 2018 the government determined a hundred priority regions, i.e., districts/cities with the highest stunting prevalence. A hundred districts/cities are spread evenly throughout the province, which varies number in each province[13]. This region determination is needed for public health nutrition measures to decrease stunting cases.

Stunting in children developed during the first two years of life (0-23 months). The pivotal causes of stunting are malnutrition[14], non-exclusive breastfeeding[15][16][17], low economic status of the family[18][19][20][21], premature births[21], low birth weight[16][20], low parental education level[18][22][23][24], living in households with 3 or more under 5 years old children[25], households with 5 - 7 family members[25], poor sanitation[20][26], and low access to the health services[20][26][27].

The determinants of stunting are well-established; however, little is known regarding the determinants in the region with a different rate of prevalence, especially in Indonesia. The current study aimed to explore the risk factors of stunting according to priority region in Indonesia based on RISKESDAS 2018. In addition, the current study updated the information regarding stunting in Indonesia from the previous RISKESDAS.

\section{Methods}

Present study analyzed secondary data obtained from the results of RISKESDAS conducted by the Ministry of Health, the Republic of Indonesia, in 2018. This survey was a nationally representative survey with a cross-sectional study conducted every five years. The population includes households in all provinces and districts/cities, i.e., 34 provinces, 416 districts, and 98 cities in Indonesia. Data collection was done by interview, measurement, and physical examination. Interviews using two instruments, i.e., Household Instruments and Individual Instruments. Details about sampling techniques, survey design, survey instruments, measurement systems, ethical clearance, and quality control have been explained elsewhere[10]. In this analysis, we use information gathered from 27,280 women with children aged 0-23 months who have fulfilled the questionnaire.

\subsection{Data management}

We defined stunting status data based on obtained RISKESDAS data of children aged 0-23 months. We determined stunting on Z-score with the [SD] calculated from height for age. Stunting determined when $Z$-score $<-2.0$. We also analyzed the factors provided based on the latest research related to stunting conducted in Indonesia. [25][28] We identified parameters provided in RISKESDAS data to be analyzed. We concern about the fundamental factors, i.e., priority region as an important parameter for the stunting cases. Priority region selected and determined by the National Team for the Acceleration of Poverty Reduction (Tim Nasional Percepatan Penanggulangan Kemiskinan: TNP2K) in 2018, i.e., 100 priority region[29]. We determined 150 control regions chosen from non-priority regions randomly. We also observed children's characteristics, i.e., age, sex, birth weight, birth height, gesta- 
tional age, weaning age, history of diarrhea within two weeks, history of immunization, initiation of early breastfeeding, exclusive breastfeeding, and supplementary feeding. Supplementary feeding determined as adequate supplementation of extra feeding, i.e., biscuits, milk, and other forms administered for the last 12 months.

Regarding parent's characteristics, we observed the educational status of parents, employment status of parents, maternal and paternal stature, maternal age of first birth, desired pregnancy status, administration of ferrous-sulfate tablets, the number of antenatal care (ANC) visits during pregnancy, and the history of pregnancy complication. Pregnancy complications were defined as the presence of gestational related-problems during pregnancy, delivery, and puerperium could be the infection, bleeding, or eclampsia.

We also observed household characteristics, i.e., the number of all family members, the number of children under five years in the household, access to the health services (Public Health Services=Pusat Kesehatan Masyarakat [Puskesmas]), fecal disposal status, and type of drinking water used. Fecal disposal categorized as standardized based on latrine usage, while the type of drinking water categorized as secured when satisfied with the criteria of secured drinking water, i.e., from branded bottled water, governmental drinking water company, and secured water springs.

\subsection{Data analysis}

Data were presented in frequency and percentage based on case and control status due to categorical data types. Chi-square analysis was performed to determine the relationship between determinants and stunting status. P-values $<0.05$ were considered statistically significant. Factors that have a p-value lower than 0.25 were involved in multivariable analysis. We analyze the final model using Binary Regression Logistics. All analyses were performed by SPSS 16.0 (IBM Corporation, NY, USA).

\section{Results}

Data were extracted from the RISKESDAS 2018, and we got a total of 27,280 children 0-23 months that met the criteria. Of them, 8,537 experienced stunting mean the prevalence based on this subset was $31.29 \%$. Based on the priority region category, most of them living in the non-priority region, i.e., 21,424 (78.5\%), and the rest $21.5 \%$ living in the priority region (Table 1a.)

Table 1a. also shows that the proportion of priority region was significantly higher in the stunting group. The proportion of aged $<12$ months was significantly lower in the case group compared to the control group. The proportion of males was also remarkable higher in the stunting group. History of diarrhea within the two weeks proportion was significantly higher in the case group, while the history of diarrhea after two weeks was not significantly different between groups. Gestational age $<37$ weeks proportion was higher in the stunting group. Birth weight and birth height also demonstrated significant differences between groups. The proportion of lower birth weight was higher in the case group, as well as the proportion of lower birth 
height. However, the missing values (not applicable data) of these two parameters were quite high. Weaned age proportion notably different as well, i.e., weaning age of $<12$ months tend to be lower in the case group. The other parameters in the children's domain, i.e., supplementary feeding, immunization history, early breastfeeding initiation, and exclusive breastfeeding, were comparable between groups.

Table $1 \mathrm{~b}$ demonstrated the characteristics in the domain of parents. Mothers and fathers who had lower education levels were higher proportion in the stunting group. There was a significant difference between the mother's employment status proportion, i.e., tend to be lower for stunting group, while the father's employment status was comparable between groups. The mother's age of first labor under 20 years tends to have a higher proportion in the case group. 
Table 1. a. Subject Characteristics of children

\begin{tabular}{|c|c|c|c|c|}
\hline \multirow[t]{2}{*}{ Characteristics } & \multicolumn{2}{|c|}{ Stunting status } & \multirow[t]{2}{*}{ P-value * } & \multirow[t]{2}{*}{ OR $[95 \% \mathrm{CI}]$} \\
\hline & $\begin{array}{c}\text { Yes } \\
\mathbf{N}=\mathbf{8 , 5 3 7}\end{array}$ & $\begin{array}{c}\text { No } \\
\text { N }=18,743\end{array}$ & & \\
\hline \multicolumn{5}{|l|}{ Priority region } \\
\hline Yes n; \% & $1996 ; 23.4$ & $3860 ; 20.6$ & 0.001 & $1,117(1,107-1,251)$ \\
\hline No n; \% & $6541 ; 76.6$ & $14883 ; 79.4$ & & \\
\hline \multicolumn{5}{|l|}{ Age } \\
\hline$<12$ months $\mathrm{n} ; \%$ & $3174 ; 37.2$ & $10533 ; 56.2$ & 0.001 & $0.461(0.438-0.486)$ \\
\hline $12-23$ months $n ; \%$ & $5363 ; 62.8$ & $8210 ; 43.8$ & & \\
\hline \multicolumn{5}{|l|}{ Sex } \\
\hline Male n; \% & $4730 ; 55.4$ & $9235 ; 49.3$ & 0.001 & $1.279(1.215-1.347)$ \\
\hline Female n; \% & $3807 ; 44.6$ & $9508 ; 50.7$ & & \\
\hline \multicolumn{5}{|l|}{ History of diarrhea } \\
\hline Yes in $<2$ weeks $\mathrm{n} ; \%$ & $715 ; 8.4$ & $1324 ; 7.1$ & 0.001 & $1.208(1,099-1,328)$ \\
\hline Yes in> 2 weeks $n ; \%$ & $351 ; 4.1$ & $706 ; 3.8$ & 0.119 & $1.112(0,976-1,268)$ \\
\hline Never n; \% & $7471 ; 87.5$ & $16713 ; 89.2$ & Ref & Ref \\
\hline \multicolumn{5}{|l|}{ Supplementary feeding } \\
\hline No $\mathrm{n} ; \%$ & $4948 ; 58.0$ & $10985 ; 58.6$ & 0.320 & $0.974(0.974-1.026)$ \\
\hline Yes n; $\%$ & $3589 ; 42.0$ & $7758 ; 41.4$ & & \\
\hline \multicolumn{5}{|l|}{ History during birth } \\
\hline \multicolumn{5}{|l|}{ Gestational age } \\
\hline$<37$ weeks n; \% & $2918 ; 34.2$ & $5996 ; 32.0$ & 0.001 & $1.104(1.046-1.166)$ \\
\hline$\geq 37$ weeks $n ; \%$ & $\begin{array}{l}5619 ; 65 . \\
8\end{array}$ & $12747 ; 68.0$ & & \\
\hline \multicolumn{5}{|l|}{ Birth weight } \\
\hline N/A n; \% & $3486 ; 40.8$ & $6961 ; 37.1$ & & \\
\hline$\leq 2500 \mathrm{~g} \mathrm{n} ; \%$ & $804 ; 9.4$ & $1005 ; 5.4$ & 0.001 & $2.030(1.838-2.242)$ \\
\hline$>2500 \mathrm{~g} \mathrm{n} ; \%$ & $4247 ; 49.7$ & $10777 ; 57.5$ & & \\
\hline \multicolumn{5}{|l|}{ Birth height } \\
\hline N/A n; \% & $4339 ; 50.8$ & $8736 ; 46.6$ & & \\
\hline$\leq 44.2 \mathrm{~cm} \mathrm{n} ; \%$ & $415 ; 4.9$ & $574 ; 3.1$ & 0.001 & $1.803(1.580-2.057)$ \\
\hline$>44.2 \mathrm{~cm} \mathrm{n} ; \%$ & $3783 ; 44.3$ & $9433 ; 50.3$ & & \\
\hline \multicolumn{5}{|l|}{ Immunization history } \\
\hline N/A n; \% & $5475 ; 64.1$ & $12779 ; 68.2$ & & \\
\hline No n; $\%$ & $884 ; 10.4$ & $1615 ; 8.6$ & 0.076 & $1.093(0.992-1.204)$ \\
\hline Yes n; \% & $2178 ; 25.5$ & $4349 ; 23.2$ & & \\
\hline \multicolumn{5}{|c|}{ Early breastfeeding initiation } \\
\hline No $\mathrm{n} ; \%$ & $3844 ; 45.0$ & $8300 ; 44.3$ & 0.257 & $1.031(0.979-1.085)$ \\
\hline Yes n; \% & $4693 ; 55.0$ & $10443 ; 55.7$ & & \\
\hline \multicolumn{5}{|c|}{ Exclusive breastfeeding } \\
\hline No $n ; \%$ & $3844 ; 45.0$ & $8300 ; 44.3$ & 0.257 & $1.031(0.979-1.085)$ \\
\hline Yes n; \% & $4693 ; 55.0$ & $10443 ; 55.7$ & & \\
\hline \multicolumn{5}{|l|}{ Weaned age } \\
\hline N/A n; \% & $215 ; 2.5$ & $459 ; 2.4$ & & \\
\hline$<12$ months $\mathrm{n} ; \%$ & $3978 ; 46.6$ & $10170 ; 54.3$ & 0.001 & $0.731(0.694-0.770)$ \\
\hline$\geq 12$ months $\mathrm{n} ; \%$ & $4344 ; 50.9$ & $8114 ; 43.3$ & & \\
\hline
\end{tabular}

\section{* Chi-Square test}

The proportion of pregnant mothers with less than four visits tends to be higher in the stunting category. Lower height, both of the mother and father tend to have a higher proportion in the stunting group. Ferrous-sulfate supplementation group tends 
to be lower in the case group, significantly. Pregnancy status and pregnancy complication proportions were comparable between groups.

A household with had three or more under-five years old children significantly had a higher proportion in the case group. (Table 1c.) Similarly, family members five to seven members, as well as eight members or more, tend to be higher in the stunting category. Families with have difficulty accessing public health services tend to have a higher proportion of stunting. Secured drinking water usage tends to have a lower proportion in the stunting cases. Fecal disposal management in the household proportion was comparable between groups.

Table 1. b. Subject Characteristics of parents conditions

\begin{tabular}{|c|c|c|c|c|}
\hline \multirow[t]{2}{*}{ Characteristics } & \multicolumn{2}{|c|}{ Stunting status } & \multirow[t]{2}{*}{ Pvalue * } & \multirow[t]{2}{*}{ OR $[95 \% \mathrm{CI}]$} \\
\hline & $\begin{array}{c}\text { Yes } \\
\mathbf{N}=\mathbf{8 , 5 3 7} \\
\end{array}$ & $\begin{array}{c}\text { No } \\
\mathrm{N}=\mathbf{1 8 , 7 4 3} \\
\end{array}$ & & \\
\hline \multicolumn{5}{|l|}{ Mother's level of education } \\
\hline High school or lower n; \% & $7456 ; 87.3$ & $15851 ; 84.6$ & 0.001 & $1.258(1.167-1.357)$ \\
\hline Higher education; $\%$ & $1081 ; 12.7$ & $2892 ; 15.4$ & & \\
\hline \multicolumn{5}{|l|}{ Mother's employment status } \\
\hline Unemployed n; \% & $4933 ; 57.8$ & $11111 ; 59.3$ & 0.021 & $0.940(0.893-0.990)$ \\
\hline Employed n; \% & $3604 ; 42.2$ & $7632 ; 40.7$ & & \\
\hline \multicolumn{5}{|l|}{ Mother's age of first labor } \\
\hline$<20$ years $\mathrm{n} ; \%$ & $2651 ; 31.1$ & $5301 ; 28.3$ & 0.001 & $1.141(1.078-1.207)$ \\
\hline$\geq 30$ years $\mathrm{n} ; \%$ & $5467 ; 64.0$ & $12474 ; 66.6$ & 0838 & $1.013(0.899-1.140)$ \\
\hline $20-29$ years $n ; \%$ & $419 ; 4.9$ & $968 ; 5.2$ & Ref & Ref \\
\hline \multicolumn{5}{|l|}{ Pregnancy status } \\
\hline Undesired n; \% & $310 ; 3.6$ & $682 ; 3.6$ & 1.000 & $0.998(0.87-1.144)$ \\
\hline Desired n; \% & $8227 ; 96.4$ & $18061 ; 96.4$ & & \\
\hline \multicolumn{5}{|l|}{ Number of ANC visits } \\
\hline$<4$ times $n ; \%$ & $2001 ; 23.4$ & $3856 ; 20.6$ & 0.001 & $1.182(1.112-1.257)$ \\
\hline$\geq 4$ times $\mathrm{n} ; \%$ & $6536 ; 76.6$ & $14887 ; 79.4$ & & \\
\hline \multicolumn{5}{|l|}{ Mother's height } \\
\hline$<150 \mathrm{~cm} \mathrm{n} ; \%$ & $3766 ; 44.1$ & $6133 ; 32.7$ & 0.001 & $1.623(1.540-1.710)$ \\
\hline$\geq 150 \mathrm{~cm} \mathrm{n} ; \%$ & $4771 ; 55.9$ & $12610 ; 67.3$ & & \\
\hline \multicolumn{5}{|l|}{ Ferrous sulfate supplementation } \\
\hline No $n ; \%$ & $1275 ; 14.9$ & $2400 ; 12.8$ & 0.001 & $1.196(1.111-1.287)$ \\
\hline Yes n; \% & $7262 ; 85.1$ & $16343 ; 87.2$ & & \\
\hline \multicolumn{5}{|l|}{ Pregnancy complication } \\
\hline Yes (at least one or more) $n ; \%$ & $987 ; 11.6$ & $2290 ; 12.2$ & 0.127 & $0.939(0.868-1.017)$ \\
\hline No $n ; \%$ & $7550 ; 88.4$ & $16453 ; 87.8$ & & \\
\hline \multicolumn{5}{|l|}{ Father's level of education } \\
\hline High school or lower $\mathrm{n} ; \%$ & $7636 ; 89.4$ & $16249 ; 86.7$ & 0.001 & $1.301(1.200-1.410)$ \\
\hline Higher education $\mathrm{n} ; \%$ & $901 ; 10.6$ & $2494 ; 13.3$ & & \\
\hline \multicolumn{5}{|l|}{ Father's employment status } \\
\hline Unemployed $n ; \%$ & $203 ; 2.4$ & $454 ; 2.4$ & 0885 & $0.981(0.830-1.160)$ \\
\hline Employed n; \% & $8334 ; 97.6$ & $18289 ; 97.6$ & & \\
\hline \multicolumn{5}{|l|}{ Father's height } \\
\hline$<160 \mathrm{~cm} \mathrm{n} ; \%$ & $2798 ; 32.8$ & $4618 ; 24.6$ & 0.001 & $1.491(1.410-1.577)$ \\
\hline$\geq 160 \mathrm{~cm} \mathrm{n} ; \%$ & 573 & 1412 & & \\
\hline & $9 ; 67.2$ & $5 ; 75.4$ & & \\
\hline
\end{tabular}

ANC: ante-natal care $*$ Chi-Square test 
Table 1. c. Subject Characteristics regarding household conditions

\begin{tabular}{|c|c|c|c|c|}
\hline \multirow[t]{2}{*}{ Characteristics } & \multicolumn{2}{|c|}{ Stunting status } & \multirow[t]{2}{*}{ P-value : } & \multirow[t]{2}{*}{ OR $[95 \% \mathrm{CI}]$} \\
\hline & $\begin{array}{c}\text { Yes } \\
\mathrm{N}=\mathbf{8 , 5 3 7}\end{array}$ & $\begin{array}{c}\text { No } \\
\mathrm{N}=\mathbf{1 8 , 7 4 3}\end{array}$ & & \\
\hline \multicolumn{5}{|c|}{$\begin{array}{l}\text { Number of under-fives in } \\
\text { household }\end{array}$} \\
\hline$\geq 3 \mathrm{n} ; \%$ & $316 ; 3.7$ & $513 ; 2.7$ & 0.001 & $1.368(1.185-1.579)$ \\
\hline $2 \mathrm{n} ; \%$ & $2119 ; 24.8$ & $4678 ; 25.0$ & 0844 & $1.006(0.948-1.068)$ \\
\hline $1 \mathrm{n} ; \%$ & $6102 ; 71.5$ & $13552 ; 72.3$ & Ref & Ref \\
\hline \multicolumn{5}{|l|}{ Members in household } \\
\hline$\geq 8$ members $\mathrm{n} ; \%$ & $840 ; 9.8$ & $1719 ; 9.2$ & 0.020 & $1.116(1.018-1.224)$ \\
\hline$\overline{5}$ - 7 members n; \% & $4400 ; 51.5$ & $9495 ; 50.7$ & 0.041 & $1.058(1.002-1.117)$ \\
\hline 1 - 4 members n; \% & $3297 ; 38.6$ & $7529 ; 40.2$ & Ref & Ref \\
\hline \multicolumn{5}{|c|}{ Limited access to health services } \\
\hline Yes n; \% & $483 ; 5.7$ & $825 ; 4.4$ & 0.001 & $1.302(1.161-1.462)$ \\
\hline No $n ; \%$ & $8054 ; 94.3$ & $17918 ; 95.6$ & & \\
\hline \multicolumn{5}{|l|}{ Fecal disposal } \\
\hline Non latrine usage $\mathrm{n} ; \%$ & $51517 ; 60.4$ & $11517 ; 61.4$ & & \\
\hline Latrine usage $\mathrm{n} ; \%$ & $3380 ; 39.6$ & $7226 ; 38.6$ & 0.105 & 0.957 (0.908-1.009) \\
\hline \multicolumn{5}{|l|}{ Drinking water } \\
\hline Unsecured n:\% & $1536 ; 18.0$ & $2933 ; 15.6$ & 0.001 & $1.183(1.105-1.266)$ \\
\hline Secured n; \% & $7001 ; 82.0$ & $15810 ; 84.4$ & & \\
\hline
\end{tabular}

under-fives: under five years old children $*$ Chi-Square test

Table 2. Binary logistic regression of parameters based on priority region

\begin{tabular}{|c|c|c|c|c|c|c|}
\hline \multirow[b]{2}{*}{ Variable } & \multicolumn{2}{|c|}{ Non-priority region } & \multicolumn{2}{|c|}{ Priority region } & \multicolumn{2}{|r|}{ Total region } \\
\hline & $\mathrm{p}$ & $\begin{array}{c}\text { Adjusted OR } \\
(95 \% \mathrm{CI})\end{array}$ & $\mathrm{p}$ & $\begin{array}{c}\text { Adjusted OR } \\
(95 \% \mathrm{CI})\end{array}$ & $\mathrm{p}$ & $\begin{array}{c}\text { Adjusted OR } \\
(95 \% \mathrm{CI})\end{array}$ \\
\hline Priority region & & & & & 0.001 & $1.141(1.072-1.214)$ \\
\hline $5 /$ more family members & 0.024 & $\begin{array}{l}\text { L.072 (1.009- } \\
1.139)\end{array}$ & & & 0.018 & $1.066(1.011-1.124)$ \\
\hline Male & 0.001 & $\begin{array}{l}1.281(1.207- \\
1.358)\end{array}$ & 0.001 & $\begin{array}{c}1.308(1.172- \\
1459)\end{array}$ & 0.001 & $1.288(1.223-1.357)$ \\
\hline $\begin{array}{l}\text { Limited access to health } \\
\text { services }\end{array}$ & 0.014 & $\begin{array}{l}\text { L.191 (1.035- } \\
1.369)\end{array}$ & & & 0.006 & $1.180(1.018-1.163)$ \\
\hline ANC visits $<4$ & 0.032 & $\begin{array}{l}\lfloor .081(1.007- \\
1.162)\end{array}$ & & & 0.013 & $1.088(1.018-1.163)$ \\
\hline $\begin{array}{l}\text { Mother's height }<150 \\
\mathrm{~cm}\end{array}$ & 0.001 & $\begin{array}{l}\text { L.589 (1.496- } \\
1.689)\end{array}$ & 0.001 & $\begin{array}{c}1.436(1.285- \\
1.604)\end{array}$ & 0.001 & $1.556(1.476-1.641)$ \\
\hline $\begin{array}{l}\text { Father with high school } \\
\text { or lower educational } \\
\text { level }\end{array}$ & 0.008 & $\begin{array}{l}\text { L.156 (1.039- } \\
1.287)\end{array}$ & & & 0.001 & $1.185(1.092-1.287)$ \\
\hline Father's height $<160 \mathrm{~cm}$ & 0.001 & $\begin{array}{l}L .138(1.294- \\
1.479)\end{array}$ & 0.001 & $\begin{array}{c}1.444(1.285- \\
1.622)\end{array}$ & 0.001 & $1.400(1.322-1.482)$ \\
\hline $\begin{array}{l}\text { No ferrous-sulfate } \\
\text { supplementation }\end{array}$ & & & 0.001 & $\begin{array}{c}1.419(1.200- \\
1.678)\end{array}$ & 0.005 & $1.200(1.034-1.213)$ \\
\hline Constant & 0.001 & 0.232 & 0.001 & 0.542 & 0.001 & 0.236 \\
\hline
\end{tabular}

ANC: ante-natal care

Present study also grouping all characteristics based on priority region status as a fundamental determinant of stunting. (Table 2.) We analyzed the characteristics in three groups, i.e., non-priority region, priority region, and total region. Present study 
identified seven risk factors in the non-priority group, four risk factors in the priority group, and nine risk factors in the total group. We found that male children, mother's height $<150 \mathrm{~cm}$, father's height $<160 \mathrm{~cm}$ were consistent risk factors either in nonpriority, priority, or total groups. There were four risk factors associated with stunting in non-priority and total group, i.e., five or more family members, limited access to health services, ANC visits $<4$, and father with high school or lower education level, while no ferrous-sulfate supplementation was the only risk factors in the priority region and total group. The odds ratio (OR) and confidence interval (CI) for each risk factors presented in Table 2 .

\section{Discussion}

The present study reports the risk factors of stunting in Indonesia. To the best of our knowledge, the present study was the first report of stunting risk factors that differentiated based on priority region status. This study also provided the prevalence of stunting based on the population study, i.e., $31.29 \%$, means consistent with the number in total RISKESDAS 2018 survey, i.e., 30.5\%[10]. TNP2K divided region based on stunting problems into priority and non-priority regions. Priority regions consist of 100 districts/cities in Indonesia. These priority regions located in Java and Bali islands, i.e., 40 regions, while 60 regions were outside Java and Bali islands[29]. There were more regions outside Java and Bali islands as priority regions, that related to socioeconomic conditions, especially those in eastern Indonesia. Indeed, development priority in all aspects is concerned in eastern Indonesia; however, appropriate strategies must be improved. Previous studies reported that resources and facilities are limited, especially in the health care services in these regions[25,30].

In this study, in all regions we found consistently, that male children were more likely to get stunting, with also the consistent $\mathrm{OR}$ in the non-priority region, priority region, and the total group of 1.28 (95\% CI: 1.207-1.358), 1.30 (95\% CI: $1.172-$ 1459), and 1.29 (95\% CI; 1.223-1.357), respectively. These results were also consistent with the 2013 RISKESDAS data [25] as well as other studies[31][32][33]. Studies also reported that boys are more susceptible to infectious diseases caused by environmental conditions and their mobilitities[34][35]. Mother's height $<150 \mathrm{~cm}$ and father's height $<160 \mathrm{~cm}$ in this analysis have a significant relationship. Other studies have found a strong relationship between father's short stature and stunting in children 24-59 months[16]. Current study showed that OR of mother's height less than $150 \mathrm{~cm}$ were comparable, i.e. 1.59 (95\% CI: 1.496-1.689) 1.44 (95\% CI:1.285-1.604) 1.56 (95\% CI: 1.476-1.641), respectively. Regarding father's height $<150 \mathrm{~cm}$, the OR in the non-priority region, priority region, and total region were 1.14 (95\% CI: 1.294-1.479), 1.44 (95\% CI: 1.285-1.622), and 1.40 (95\% CI:1.322-1.482), respectively.

In the priority and total region population, we found that no ferrous-sulfate supplementation were the only risk factors with the OR of 1.42 (1.200-1.678) and 1.20 (1.034-1.213) in priority and total region, respectively. Our findings indicated that administration of ferrous-sulfate tablets is important to support optimal maternal nutrition because this supplementation is needed to ensure optimal intra-uterine fetal growth[36][30] Trials have examined the benefits of iron/folic acid and micronutri- 
ents supplementations during pregnancy in promoting fetal growth, birth length and postnatal growth[37][38]. There is a strong relationship between stunting and consumption of animal proteins, especially various types of animal proteins[14][39]. We did not find the relationship between ferrous-sulfate supplementation and stunting in the non-priority region, but lack of additional data founded in the study to conclude the possible cause of this condition.

In the total region from the current study showed that father with high school or lower of education level was related to stunting (OR=1.19 (95\% CI: 1.092-1.287), but nor in mother's education level. Previous studies[40] concluded that low education related to stunting. The relationship between parent's education level and stunting is well elucidated but did not differentiate which is the most influenced, whether their father or mother [19][20] In general, the chance of stunting for children is twice higher in the lower level of parental education[40], while this study just showed 1.19 times for lower father's education level.

The family member consists of five or more members was the risk factors as well in the total region with the OR of 1.07 (95\% CI: 1.011-1.124). This condition also corresponded with household issues, i.e., the number of under-five years children living in the house. Previous studies[25] concluded; accordingly, this can be due to a location in the availability of food, improper childcare practices, and accessibility of suboptimal family facilities[32][41] Limited access to the health services and ANC visits less than four times were the risk factors for stunting both in non-priority and total regions. These two parameters were related to healthcare services. These findings were the classical problems and still existed to date, as reported previously[40][25]. Poor access to health services and living in remote rural areas were the crucial determinants in the household level [25].

Other studies concluded the other risk factors, i.e., low birth weight and height[7] [24][34], age, and maternal age during pregnancy. Studies reported that children aged $<12$ months tend to get stunting[15] [24][25], while other studies concluded that aged 12-23 years more likely to get stunting[25][7]. However, we did not find any relationship between the age of children, birth weight/ height, and maternal age during pregnancy to stunting status. Future studies that involved more parameters such as genetic factors and molecular biomarkers should be conducted to elucidate the risk factors of stunting in Indonesia and globally.

\section{Conclusion}

The present study concluded that there were different risk factors for stunting based on priority region status. Male children, mother's height $<150 \mathrm{~cm}$, and father's height $<160 \mathrm{~cm}$ were the constant risk factors for stunting in all region groups. In the total group, we concluded that priority region, five or more family members, male children, limited access to health services, ANC visits $<4$, mother's height $<150 \mathrm{~cm}$, the father with high school or lower educational level, father's height $<160 \mathrm{~cm}$, and no ferrous-sulfate supplementation altogether were the risk factors for stunting in Indonesia. 


\section{Acknowledgments}

We thank the Faculty of Sports Science, Universitas Negeri Semarang, for the Research Grant. We also thank the National Institute of Health Research and Development, Ministry of Health, the Republic of Indonesia, for providing RISKESDAS 2018 data.

\section{References}

[1] Oh SH, Ahn DC, Kim YS. A study on the mechanical properties and springback of 3D aluminum sheets. Int J Precis Eng Manuf 2016;17:671-7.

[2] World Health Organization. Global targets 2025 to improve maternal, infant and young children nutrition. 2017.

[3] Stirnemann J, Villar J, Salomon LJ, Ohuma E, Ruyan P, Altman DG, et al. International estimated fetal weight standards of the INTERGROWTH-21st Project. Ultrasound Obstet Gynecol 2017;49:478-86.

[4] Watanabe K, Flores R, Fujiwara J, Tran LTH. Early Childhood Development Interventions and Cognitive Development of Young Children in Rural Vietnam. J Nutr 2005;135:1918-25.

[5] Kar BR, Rao SL, Chandramouli BA. Cognitive development in children with chronic protein energy malnutrition. Behav Brain Funct 2008;4:1-12.

[6] Sokolovic N, Selvam S, Srinivasan K, Thankachan P, Kurpad A V., Thomas T. Catch-up growth does not associate with cognitive development in Indian school-age children. Eur J Clin Nutr 2014;68:14-8.

[7] Prendergast AJ, Humphrey JH. The stunting syndrome in developing countries. Paediatr Int Child Health 2014;34:250-65.

[8] Perignon M, Fiorentino M, Kuong K, Burja K, Parker M, Sisokhom S, et al. Stunting, poor iron status and parasite infection are significant risk factors for lower cognitive performance in Cambodian school-aged children. PLoS One 2014;9.

[9] Victora CG, Adair L, Fall C, Hallal PC, Martorell R, Richter L, et al. Maternal and child undernutrition: consequences for adult health and human capital. Lancet 2008;371:34057.

[10] Badan Penelitian dan Pengembangan Kesehatan. Laporan Nasional Riset Kesehatan Dasar: RISKESDAS (Indonesia Basic Health Survey) tahun 2018. 2019.

[11] WHO. Nutrition Landscape Information System (NLIS). Nutr Landacape Inf Syst 2018:1-51.

[12] Badan Penelitian dan Pengembangan Kesehatan. Riskesdas Biomedis Riset Kesehatan Dasar 2013. Jakarta: 2013.

[13] Tim Nasional Percepatan Penanggulangan Kemiskinan: TNP2K (National Team for the Accelaration of Poverty Reduction). Strategi Nasional Percepatan Pencegahan Stunting 2018-2024 (National Strategy for Accelerating Stunting Prevention 2018-2024). 2018.

[14] Gibson RS, Manger MS, Krittaphol W, Pongcharoen T, Gowachirapant S, Bailey KB, et al. Does zinc deficiency play a role in stunting among primary school children in NE Thailand? Br J Nutr 2007;97:167-75.

[15] Torlesse H, Cronin AA, Sebayang SK, Nandy R. Determinants of stunting in Indonesian children: Evidence from a cross-sectional survey indicate a prominent role for the water, sanitation and hygiene sector in stunting reduction. BMC Public Health 2016;16:1-11.

[16] Rachmi CN, Agho KE, Li M, Baur LA. Stunting coexisting with overweight in 2.0-4.9year-old Indonesian children: Prevalence, trends and associated risk factors from repeated cross-sectional surveys. Public Health Nutr 2016;19:2698-707. 
[17] Ramli, Agho KE, Inder KJ, Bowe SJ, Jacobs J, Dibley MJ. Prevalence and risk factors for stunting and severe stunting among under-fives in North Maluku province of Indonesia. BMC Pediatr 2009;9:64.

[18] Fernald LCH, Kariger P, Hidrobo M, Gertler PJ. Socioeconomic gradients in child development in very young children: Evidence from India, Indonesia, Peru, and Senegal. Proc Natl Acad Sci U S A 2012;109:17273-80.

[19] Sari M, de Pee S, Bloem MW, Sun K, Thorne-Lyman AL, Moench-Pfanner R, et al. Higher Household Expenditure on Animal-Source and Nongrain Foods Lowers the Risk of Stunting among Children 0-59 Months Old in Indonesia: Implications of Rising Food Prices. J Nutr 2010;140:195S-200S.

[20] Semba RD, Moench-Pfanner R, Sun K, De Pee S, Akhter N, Rah JH, et al. Consumption of micronutrient-fortified milk and noodles is associated with lower risk of stunting in preschool-aged children in Indonesia. Food Nutr Bull 2011;32:347-53.

[21] Prawirohartono E, Nurdiati D, Hakimi M. Prognostic factors at birth for stunting at 24 months of age in rural Indonesia. Paediatr Indones 2016;56:48.

[22] Berger SG, de Pee S, Bloem MW, Halati S, Semba RD. Malnutrition and Morbidity Are Higher in Children Who Are Missed by Periodic Vitamin A Capsule Distribution for Child Survival in Rural Indonesia. J Nutr 2007;137:1328-33.

[23] Oddo VM, Rah JH, Semba RD, Sun K, Akhter N, Sari M, et al. Predictors of maternal and child double burden of malnutrition in rural Indonesia and Bangladesh. Am J Clin Nutr 2012;95:951-8.

[24] Schmidt MK, Muslimatun S, West CE, Schultink W, Gross R, Hautvast JGAJ. Nutritional Status and Linear Growth of Indonesian Infants in West Java Are Determined More by Prenatal Environment than by Postnatal Factors. J Nutr 2002;132:2202-7.

[25] Titaley CR, Ariawan I, Hapsari D, Muasyaroh A, Dibley MJ. Determinants of the stunting of children under two years old in Indonesia: A multilevel analysis of the 2013 Indonesia basic health survey. Nutrients 2019;11.

[26] Bardosono S, Sastroamidjojo S, Lukito W. Determinants of child malnutrition during the 1999 economic crisis in selected poor areas of Indonesia. Asia Pac J Clin Nutr 2007;16:512-26.

[27] Anwar F, Khomsan A, Sukandar D, Riyadi H, Mudjajanto ES. High participation in the Posyandu nutrition program improved children nutritional status. Nutr Res Pract 2010;4:208.

[28] Akram R, Sultana M, Ali N, Sheikh N, Sarker AR. Prevalence and Determinants of Stunting Among Preschool Children and Its Urban-Rural Disparities in Bangladesh. Food Nutr Bull 2018;39:521-35.

[29] Tim Nasional Percepatan Penanggulangan Kemiskinan: TNP2K (National Team for the Accelaration of Poverty Reduction). 100 kabupaten/Kota Prioritas untuk intervensi anak kerdil (stunting). 2017.

[30] Bhutta ZA, Das JK, Rizvi A, Gaffey MF, Walker N, Horton S, et al. Evidence-based interventions for improvement of maternal and child nutrition: What can be done and at what cost? Lancet 2013;382:452-77.

[31] Mostafa Kamal SM. Socio-economic determinants of severe and moderate stunting among under-five children of rural Bangladesh. Malays J Nutr 2011;17:105-18.

[32] García Cruz LM, González Azpeitia G, Reyes Súarez D, Santana Rodríguez A, Loro Ferrer JF, Serra-Majem L. Factors associated with stunting among children aged 0 to 59 months from the central region of Mozambique. Nutrients 2017;9:1-16.

[33] Aryastami NK, Shankar A, Kusumawardani N, Besral B, Jahari AB, Achadi E. Low birth weight was the most dominant predictor associated with stunting among children aged 12-23 months in Indonesia. BMC Nutr 2017;3:1-6.

[34] Hansen Pupp I, Hellström-Westas L, Elsmén E. Preterm male infants need more initial respiratory and circulatory support than female infants. Acta Paediatr Int J Paediatr 
2004;93:529-33

[35] Wamani H, Åstrøm AN, Peterson S, Tumwine JK, Tylleskär T. Boys are more stunted than girls in Sub-Saharan Africa: A meta-analysis of 16 demographic and health surveys. BMC Pediatr 2007;7:1-10.

[36] Leroy JL, Ruel M, Habicht JP. Critical windows for nutritional interventions against stunting. Am J Clin Nutr 2013;98:854-5.

[37] Ramakrishnan U, Grant FK, Goldenberg T, Bui V, Imdad A, Bhutta ZA. Effect of multiple micronutrient supplementation on pregnancy and infant outcomes: A systematic review. Paediatr Perinat Epidemiol 2012;26:153-67.

[38] Roberfroid D, Huybregts L, Lanou H, Ouedraogo L, Henry MC, Meda N, et al. Impact of prenatal multiple micronutrients on survival and growth during infancy: A randomized controlled trial. Am J Clin Nutr 2012;95:916-24.

[39] Kahssay M, Woldu E, Gebre A, Reddy S. Determinants of stunting among children aged 6 to 59 months in pastoral community, Afar region, North East Ethiopia: unmatched case control study. BMC Nutr 2020;6:1-8.

[40] Beal T, Tumilowicz A, Sutrisna A, Izwardy D, Neufeld LM. A review of child stunting determinants in Indonesia. Matern Child Nutr 2018;14:1-10.

[41] Leal VS, de Lira PIC, de Menezes RCE, OliveiraI JS, Sequeira LA de S, de Andrade SLLS, et al. Factors associated with the decline in stunting among children and adolescents in Pernambuco, northeastern Brazil. Rev Saude Publica 2012;46:234-41. 